\title{
Evaluation of the Influence of the Heavy Metals Content on the Possibility to Use the Waters from selected Strzelin Quarry Lakes for Agricultural Irrigation
}

\author{
Bartosz Jawecki ${ }^{1 *}$, Kamila Pawłowska² \\ 1 Wrocław University of Environmental and Life Sciences, Institute of Landscape Architecture, ul. Grunwaldzka \\ 55, 50-357 Wrocław, Poland \\ 2 PhD Student, Wrocław University of Environmental and Life Sciences, Institute of Landscape Architecture, \\ ul. Grunwaldzka 55, 50-357 Wrocław, Poland \\ * Corresponding author's e-mail: bartosz.jawecki@upwr.edu.pl
}

\begin{abstract}
The article presents the evaluation of the influence of the heavy metals content in the water from selected Strzelin Quarry Lakes located in Central Europe) on the possibility to use the water for irrigation. The guidelines provided by FAO and in PN-84/C-04635 were the basis of the evaluation. The water $\mathrm{pH}$ ranged from 7.1-9.0, on average 7.8. The zinc content was in the range from $0.40-29.00 \mu \mathrm{g} \cdot \mathrm{dm}^{-3}$, on the average $14.40 \mu \mathrm{g} \cdot \mathrm{dm}^{-3}$, while the content of copper ranged from $0.00-50.10 \mu \mathrm{g} \cdot \mathrm{dm}^{-3}$, on average $21.13 \mu \mathrm{g} \cdot \mathrm{dm}^{-3}$. The cadmium content fell into the range from $0.00-5.50 \mu \mathrm{g} \cdot \mathrm{dm}^{-3}$, on the average $0.83 \mu \mathrm{g} \cdot \mathrm{dm}^{-3}$, and the lead content ranged from $0.00-18.10 \mu \mathrm{g} \cdot \mathrm{dm}^{-3}$, on average $3.16 \mu \mathrm{g} \cdot \mathrm{dm}^{-3}$. The chromium content ranged from $0.00-21.00 \mu \mathrm{g} \cdot \mathrm{dm}^{-3}$, on average $4.26 \mu \mathrm{g} \cdot \mathrm{dm}^{-3}$ and, finally, the content of nickel ranged from $0.00-39.80 \mu \mathrm{g} \cdot \mathrm{dm}^{-3}$, on average $6.70 \mu \mathrm{g} \cdot \mathrm{dm}^{-3}$. The values of the analysed heavy metals were similar to the concentrations noted in natural lakes and artificial water reservoirs. As far as the heavy metal content is concerned, the water from the selected Strzelin Quarry Lakes met the requirements that allow using it for the purposes of agricultural irrigation.
\end{abstract}

Keywords: irrigation, Strzelin Quarry Lakes, heavy metals, water reservoir, quarry lake, water quality

\section{INTRODUCTION}

The fresh water deficit on Earth was estimated at 230 billion $\mathrm{m}^{3} / \mathrm{year}$ in 2000 ; this value takes into account the water for agricultural and industrial purposes (Domashenko and Vasilyev, 2018). The total amount of freshwater in Europe (approx. $2270 \mathrm{~km}^{3} /$ year) shows that the water resources are relatively abundant (EEA Report No 2/2009). In Poland, the average discharge of surface waters is approx. $58.6 \mathrm{~km}^{3}$, the average water resource index is $1.4 \mathrm{dam}^{3} /$ year per person (GUS 2019). According to estimations, the water resources in Europe amount to approx. $4750 \mathrm{~m}^{3} /$ year per person on average, it shows that Poland is one of the countries with the poorest water resources (Walczykiewicz, 2014, Łabędzki, 2016, GUS, 2019). The quality of the Polish surface water is low (Patro \& Zubala, 2012). The low quality and deficiency of water, compels the use of irrigation (also agricultural irrigation) water from different sources, which allows for the efficient use of poor water resources (Tarjuelo et al., 2010, Lykhovyd et al., 2019, Jawecki et al., 2019a).

Quarry lakes often emerge in mine pits, after the exploitation of mineral deposits is over; the water resources contained in these lakes can be used by agriculture and the economy (Axler et al., 1998, Klapper \& Geller, 2001, Ramstedt et al., 2003, Doupe \& Lymbery, 2005, Kleeberg \& Grüneberg, 2005, Nixdorf et al., 2005, McCullough, 2008, Schultze et al., 2010, Czerniawska-Kusza \& Brożonowicz, 2014, Jawecki, 2017, Jawecki \& Mirski, 2018, Jawecki et al., 2019a). Depending on the excavated natural resources and mining technology used, pit lakes or quarry 
lakes, may accumulate even millions of cubic metres of water (Doyle \& Runnells, 1997, Axler et al., 1998, Ramstedt et al., 2003, Denimal et al., 2005, Kleeberg \& Grüneberg, 2005, Nixdorf et al., 2005, Molenda, 2006, McCullough \& Lund, 2006, Kołodziejczyk, 2009, Schultze et al., 2010, Chudzik, 2012, Singleton et al., 2013, Kumar et al., 2016, Jawecki et al., 2018, Jawecki 2019, Jawecki et al., 2019b).

There are many ways to use the water retained in quarry lakes; for example, it can be used: for fish breeding, as a source of potable water, for agricultural and horticultural irrigation, source of industrial water, etc. (Axler et al., 1998, Klapper \& Geller, 2001, Galas, 2003, Castendyk et al., 2005, Doupé \& Lymbery, 2005, McCullough \& Lund, 2006, McCullough, 2008, Kumar et al., 2009, Schultze et al., 2010, Ravazzani et al., 2011, Singleton et al., 2013, Jawecki et al., 2019a). Since Poland is classified as a country with low water resources (Patro \& Zubala, 2012, Walczykiewicz, 2014, GUS 2019), using the water from flooded mining pits may become important (Jawecki et al., 2019a). This is true especially in the areas with poor water resources (Doupé \& Lymbery, 2005, McCullough \& Lund, 2006, Kumar et al., 2009, Ravazzani et al., 2011, Jawecki et. al. 2019a, Jawecki et al., 2019b). However, the use of water accumulated in mining pits depends largely on its quality and quantity (Doyle \& Runnells, 1997, Axler et al., 1998, Grünewald, 2001, Klapper \& Geller, 2001, Castendyk et al., 2005, Denimal et al., 2005, Doupé \& Lymbery, 2005, McCullough \& Lund, 2006, McCullough, 2008, Schultze et al., 2010, Kumar et al., 2016, Jawecki et al., 2018, Jawecki \& Mirski, 2018, Jawecki et al., 2019a). The concentration of heavy metals in surface and groundwater, among others depends of the mineralogical and geological structure, the type of excavated raw material, as well as the processing and mining technology (Stottmeister et al., 1999, Ramstedt et al., 2003, McCullough, 2008, Kumar et al., 2009, Schultze et al., 2010, Hinwood et al., 2012, Kumar et al., 2016, Malczewska et al. 2018).

The aim of the research was to evaluate the usability of the surface water from selected Strzelin Quarry Lakes for the agricultural irrigation, in terms of the heavy metal content. This article is a continuation of the publication of the usability of the water from selected Strzelin Quarry Lakes for agricultural irrigation, published by Jawecki and co-workers (2019a).
The quoted paper (Jawecki et al., 2019a) presented the evaluation of the possibility to use the water from selected Strzelin Quarry Lakes for agricultural irrigation, where the following indicators were analysed and assessed: electrical conductivity, Sodium Adsorption Ratio, Total Dissolved Solids, water $\mathrm{pH}, \mathrm{BOD}_{5}$, and ion concentrations of: nitrates, sulphates, chlorides, sodium, manganese, and iron. The authors stated (Jawecki et al. 2019a) that in terms of the analysed indicators, the water from the Strzelin Quarry Lakes met (with some minor limitations) the requirements that enable its use for agricultural irrigation, in particular sprinkler irrigation.

\section{MATERIALS AND METHODOLOGY}

The Strzelin Quarry Lakes are located in Central Europe, in the south-eastern part of the Lower Silesian Voivodeship, County Strzelin (Fig. 1). The characteristics of the spatial development and land use, geological structure, impact of Strzelin quarries on the environment and reclamation of Strzelin quarries were presented among others in the publications of Jawecki and co-workers (Jawecki, 2017, Jawecki \& Mirski, 2018, Jawecki, 2019, Jawecki et al., 2019a, Jawecki et al., 2019b).

Water sampling was conducted in 5 quarries (3 quarries were closed, 1 were quarries active, and 1 quarry was periodically active), the basic characteristics of which are presented in publication by Jawecki and co-workers (2019a). The samples of water were collected from 2 granite quarries (Q1-G, Q3-G) 1 tonalite, diorite and granite quarry (Q2-TDG), 1 quartzite schist quarry (Q4-QS), 1 marble quarry (Q5-M). Four of the quarries are non-outflow (Q1-G, Q2-TDG, Q3-G, Q4-QS), the water from one quarry (Q5-M) runs off by gravity to a drainage ditch, the part of water from two quarries (Q1-G, Q4-QS) is periodically pumped out and discharged outside the quarry (Jawecki et al. 2019a).

The methodology of sampling (depth from water surface, distance from the shore, hour of sample collection, measurement period) were presented in the articles of Jawecki and co-workers (2019a) and Jawecki \& Mirski (2018). The methodology for calculating the water surface area and depth of the analysed Strzelin Quarry Lakes were presented in the article of Jawecki and co-workers (2019a). 


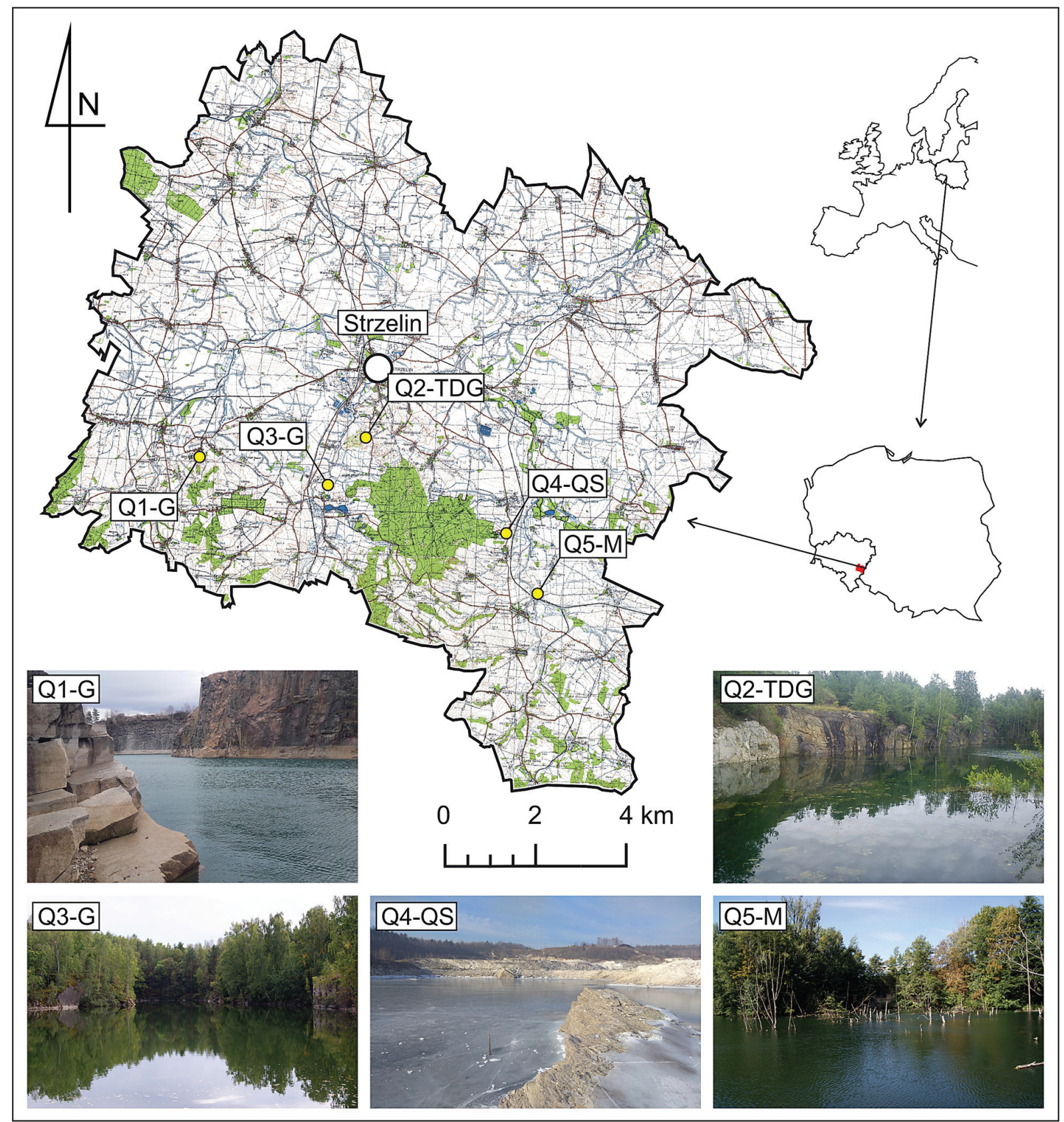

Fig. 1. Strzelin Quarry Lakes (selected) - views and location (map: license

No. MGW.I.7522.524.2016_02_N by Lower Silesian Voivodeship (Jawecki et al. 2019a, modified by Jawecki B.). The symbol on map means: granite quarry: Q1-G and Q3-G, tonalite, diorite and granite quarry: Q2-TDG, quartzite schist quarry: Q4-QS, marble quarry: Q5-M

The samples of quarry water were analysed in the laboratory of Wroclaw University of Environmental and Life Sciences (Faculty Environmental Research Laboratory), pursuant to the reference test methodologies and/or Polish Reference Standards. The content of $\mathrm{Zn}, \mathrm{Cu}, \mathrm{Cd}, \mathrm{Pb}, \mathrm{Cr}$, Ni, was calculated, along with the $\mathrm{pH}$. The obtained results were classified by using the Polish Reference Standard PN-84/C-04635 (Treder, 2016, Kaniszewski \& Treder, 2018) and FAO guidelines (Ayers \& Westcott, 1985). the average values from the measurement period of concentration of heavy metals $(\mathrm{Zn}$, $\mathrm{Cu}, \mathrm{Cd}, \mathrm{Pb}, \mathrm{Cr}, \mathrm{Ni}$,) and water $\mathrm{pH}$ were used for evaluating possibility to use the water from the selected Strzelin Quarry Lakes for irrigation. The overall evaluation were made by adopting the worst average value of the analysed indicators. The methodology of calculation of average value of $\mathrm{pH}$, standard deviation of average concentration of heavy metals, were presented in a paper by Jawecki and co-workers (2019a). 


\section{RESULTS AND DISCUSSION}

The average $\mathrm{pH}$ of water in selected Strzelin Quarry Lakes fell into the range 7.45-8.06 (Table 1), with the most frequently noted $\mathrm{pH}$ value of 8.4 , although the $\mathrm{pH}$ of water in the analysed quarries ranged from 7.1-9.0 (Table 1), and the highest values $(\mathrm{pH} 9.0)$ were found in the $\mathrm{Q} 3-\mathrm{G}$ granite quarry (Jawecki et al., 2019a), which has the characteristic properties of an eutrophic reservoir (Ejsmont-Karabin, 1995, Jawecki \& Mirski, 2018, Jawecki et. al., 2019a). The highest values of water $\mathrm{pH}$ in the analysed quarry lakes were noted in spring and summer. The strong development of phytoplanctone, the intensive photosynthesis in summer, may lead to an increase of the water $\mathrm{pH}$ (Puczyńska \& Skrzypski, 2009, Wiejaczka, 2011). The authors who were investigated the flooded marble, limestone, and quartzite quarries obtained similar results (pH 7.7-8.4) (Galas 2003, Czerniawska-Kusza \& Brożonowicz, 2014, Jawecki \& Mirski, 2018). The higher values (pH 7.34-9.74) were found in limestone quarries in USA, Nebraska State (Mayne, 1994). The $\mathrm{pH}$ values obtained by Jawecki and Mirski (2018) in eutrophic granite quarries ranged from 7.2-9.3. In the granite quarry (Q3-G), the water $\mathrm{pH}$ value (9.0 and 8.6) exceeded the range observed in natural lakes $(\mathrm{pH}$ 6.5-8.5) and the range ( $\mathrm{pH}$ 6.5-8.4) recommended by FAO for the water used in irrigation (Ayers \& Westcott, 1985). The water $\mathrm{pH}$ value of 8.0 , recommended by Polish Reference Standard PN-84/C-04635 for irrigation (Kaniszewski \&Treder, 2018) was exceeded mainly in the summer, in $56 \%$ of the samples (Jawecki et al. 2019a). A wider evaluation of the influence of $\mathrm{pH}$ of the analysed quarries of the suitability of water for use in irrigation was presented in the quoted study by Jawecki (2019a).
The average zinc content in the analysed quarry lakes fell into the range $11.32-21.02 \mu \mathrm{g} \cdot \mathrm{dm}^{-3}$, (Fig. 2, Table 1). The highest content (29.00 $\mu \mathrm{g} \cdot \mathrm{dm}^{-3}$ ) was noted in the Q5-M marble quarry (Table 1), and the lowest one $\left(0.40 \mu \mathrm{g} \cdot \mathrm{dm}^{-3}\right)$ in the Q3-G granite quarry (Table 1). The zinc content found in the Strzelin Quarry Lakes was similar to the values noted in lakes $\left(0.66-15.8 \mu \mathrm{g} \cdot \mathrm{dm}^{-3}\right)$ (Piotrowski, 1997, Preseli \& Voltas, 2007, Zeng et al., 2012, Zeng et al., 2013, Gwoździński et al., 2014, Wojtkowska, 2014, Vukosav et al., 2014), the lower values of zinc concentration $\left(<5.0-29 \mu \mathrm{g} \cdot \mathrm{dm}^{-3} 64.0-197.0 \mu \mathrm{g} \cdot \mathrm{dm}^{-3}\right)$ found in water reservoirs 'Avila-Pérez et al., 1999, Karadede \& Ünlü, 2000, Rosińska \& Dąbrowska, 2011, Frankowski \& Zbierska, 2015). At the same time, they are decidedly lower than the zinc content $\left(0.01-59.0 \mathrm{mg} \cdot \mathrm{dm}^{-3}\right)$ noted in the quarry lakes after the excavation of metal ores (Ramstedt et al., 2003, McCullough, 2008, Kumar et al., 2009) as well as in the coal and lignite pit lakes (0.5-46.0 $\mathrm{mg} \cdot \mathrm{dm}^{-3}$ (Stottmeister et al., 1999, Kumar et al., 2009, Schultze et al., 2010, Kumar et al., 2016)). As the zinc content was below $2.0 \mathrm{mg} \cdot \mathrm{dm}^{-3}$ in the analysed water, it did not lead to any restrictions in using the water from the analysed quarry lakes for the irrigation purposes (PN-84/C-04635, Ayers \& Westcott, 1985, Park et al., 2014, Kaniszewski \& Treder, 2018).

The average copper content in the analysed quarry lakes fell into the range 18.16-24.04 $\mu \mathrm{g} \cdot \mathrm{dm}^{-3}$, (Fig. 2, Table 1). The highest concentration $\left(50.10 \mu \mathrm{g} \cdot \mathrm{dm}^{-3}\right)$ was noted in the Q5-M marble quarry (Table 1). However, in December 2016, no copper at all was found in the Q3-G and Q4-QS quarry lakes (Table 2). The copper content found in the Strzelin Quarry Lakes was similar to the values noted in lakes $\left(0.13-41.5 \mu \mathrm{g} \cdot \mathrm{dm}^{-3}\right)$

Table 1. Maximum, minimum and average value of $\mathrm{pH}$ and concentration of $\mathrm{Zn}, \mathrm{Cu}, \mathrm{Cd}, \mathrm{Pb}, \mathrm{Cr}$, $\mathrm{Ni}$ in the water of the selected Strzelin Quarry Lakes

\begin{tabular}{|c|c|c|c|c|c|c|}
\hline Item & Parameter & Q1-G & Q2-TDG & Q3-G & Q4-QS & Q5-M \\
\hline 1. & $\mathrm{pH}(-)$ & $\frac{8.06}{7.6-8.4}$ & $\frac{7.98}{7.6-8.4}$ & $\frac{7.73}{7.2-9.0}$ & $7.1-8.2$ & $\frac{7.90}{7.5-8.4}$ \\
\hline 2. & $\operatorname{Zinc}\left(\mu \mathrm{g} \cdot \mathrm{dm}^{-3}\right)$ & $\frac{12.06 \pm 6.86}{7.70-20.50}$ & $\frac{15.46 \pm 12.56}{7.50-28.50}$ & $\frac{11.32 \pm 9.65}{0.40-18.80}$ & $\frac{12.14 \pm 6.37}{3.10-15.20}$ & $\frac{21.02 \pm 10.87}{7.10-29.00}$ \\
\hline 3. & Copper $\left(\mu \mathrm{g} \cdot \mathrm{dm}^{-3}\right)$ & $\frac{18.82 \pm 20.23}{4.70-46.00}$ & $\frac{22.88 \pm 19.48}{3.20-39.30}$ & $\frac{18.16 \pm 22.98}{0.00-46.80}$ & $\frac{21.74 \pm 21.99}{0.00-43.40}$ & $\frac{24.04 \pm 20.71}{7.80-50.10}$ \\
\hline 4. & Cadmium $\left(\mu \mathrm{g} \cdot \mathrm{dm}^{-3}\right)$ & $\frac{0.50 \pm 1.39}{0.00-2.50}$ & $\frac{0.56 \pm 1.13}{0.00-2.10}$ & $\frac{1.48 \pm 2.97}{0.00-5.50}$ & $\frac{0.84 \pm 1.72}{0.00-3.20}$ & $\frac{0.76 \pm 1.43}{0.00-2.60}$ \\
\hline 5. & Lead $\left(\mu \mathrm{g} \cdot \mathrm{dm}^{-3}\right)$ & $\frac{3.62 \pm 10.05}{0.00-18.10}$ & $\frac{2.52 \pm 7.00}{0.00-12.60}$ & $\frac{3.06 \pm 8.49}{0.00-15.30}$ & $\frac{3.38 \pm 9.38}{0.00-16.90}$ & $\frac{3.20 \pm 8.88}{0.00-16.00}$ \\
\hline 6. & Chromium $\left(\mu \mathrm{g} \cdot \mathrm{dm}^{-3}\right)$ & $\frac{6.24 \pm 10.71}{0.00-17.30}$ & $\frac{3.72 \pm 6.75}{0.00-12.00}$ & $\frac{6.20 \pm 11.59}{0.00-21.00}$ & $\frac{2.06 \pm 5.38}{0.00-9.80}$ & $\frac{3.10 \pm 6.17}{0.00-11.40}$ \\
\hline 7. & Nickel $\left(\mu \mathrm{g} \cdot \mathrm{dm}^{-3}\right)$ & $\frac{7.98 \pm 22.08}{0.00-39.80}$ & $\frac{5.12 \pm 12.60}{0.00-23.20}$ & $\frac{10.3 \pm 15.02}{0.00-26.10}$ & $\frac{0.46 \pm 1.28}{0.00-2.30}$ & $\frac{9.66 \pm 14.34}{0.00-24.90}$ \\
\hline
\end{tabular}



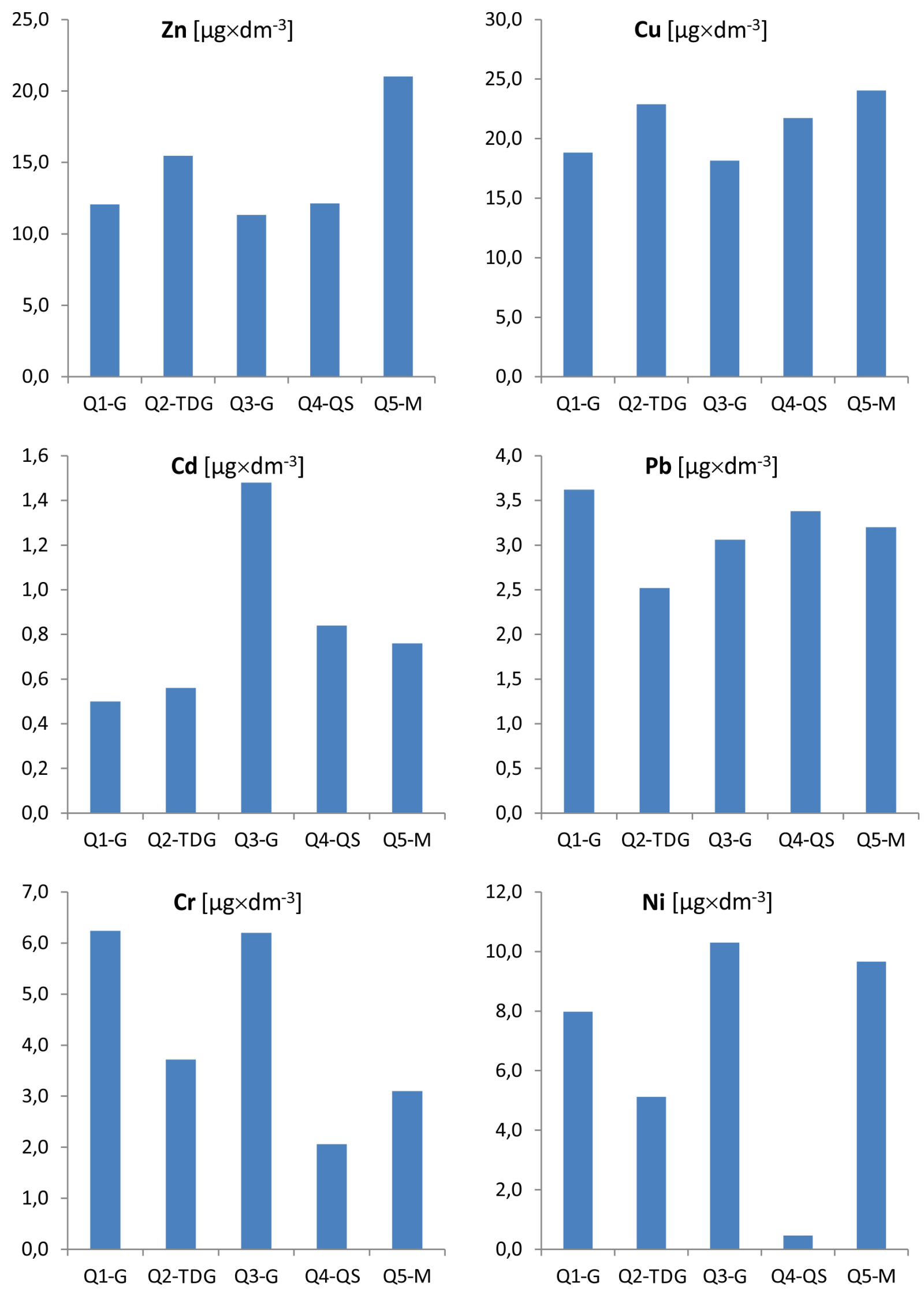

Fig. 2. Average concentrations of selected heavy metals in the waters of the analysed selected Strzelin Quarry Lakes 
(Piotrowski, 1997, Pertsemli \& Voutsa, 2007, Zeng et al., 2012, Zeng et al. 2013, Gwoździński et al., 2014, Wojtkowska, 2014, Vukosav et al., 2014) and the medium values of copper concentration $\left(<3.0-12.0 \mu \mathrm{g} \cdot \mathrm{dm}^{-3}, 14.0-22.0 \mu \mathrm{g} \cdot \mathrm{dm}^{-3}\right.$, $\left.\sim 58.0 \sim 138.0 \mu \mathrm{g} \cdot \mathrm{dm}^{-3}\right)$ noted in water reservoirs (Avila-Pérez et al., 1999, Karadede \& Ünlü, 2000, Rosińska \& Dąbrowska, 2011, Frankowski $\&$ Zbierska, 2015). At the same time, the value was decidedly lower than the zinc concentration $\left(0.01-36.0 \mathrm{mg} \cdot \mathrm{dm}^{-3}\right)$ noted in the quarry lakes after metal ore mining (Ramstedt et. al. 2003, McCullough, 2008, Kumar et al., 2009) as well as in the coal and lignite pit lakes $\left(0.5-46.0 \mathrm{mg} \cdot \mathrm{dm}^{-3}\right)$ (Stottmeister et al., 1999, Kumar et al., 2009). As the copper content in the analysed water was below $0.2 \mathrm{mg} \cdot \mathrm{dm}^{-3}$ it did not lead to any restrictions in using the water from the analysed quarry lakes for the irrigation purposes (PN-84/C-04635, Ayers $\&$ Westcott, 1985, Park et al., 2014, Kaniszewski $\&$ Treder, 2018).

The average cadmium content in the analysed quarry lakes ranged from $0.5-1.48 \mu \mathrm{g} \cdot \mathrm{dm}^{-3}$, (Fig. 2, Table 1). The highest concentration (5.5 $\mu \mathrm{g} \cdot \mathrm{dm}^{-3}$ was noted in the Q3-G marble quarry (Table 1). In autumn and winter, no cadmium was detected in $64 \%$ of the water samples from the analysed Strzelin Quarry Lakes (Table 2). The cadmium content in the waters of the analysed quarry lakes is similar to the lower values (0.009$\left.1.0 \mu \mathrm{g} \cdot \mathrm{dm}^{-3}, 2.4-15.3 \mu \mathrm{g} \cdot \mathrm{dm}^{-3}\right)$ noted in lakes, in particular uncontaminated ones (Piotrowski, 1997, Gwoździński et al., 2014, Zeng et al., 2012, Zeng et al., 2013, Elzwayie et al., 2017). At the same time, they are decidedly lower than the zinc content $\left(0.02-0.16 \mathrm{mg} \cdot \mathrm{dm}^{-3}\right)$ noted in the quarry lakes after the excavation of metal ores (Ramstedt et al., 2003, McCullough, 2008, Kumar et al., $2009)$ and in coal and lignite pit lakes ((0.001$0.023 \mathrm{mg} \cdot \mathrm{dm}^{-3}$ ) (Stottmeister et al., 1999, Kumar et al., 2009, Hinwood et al., 2012)). As the cadmium content in the analysed water was below $0.1 \mathrm{mg} \cdot \mathrm{dm}^{-3}$ it did not lead to any restrictions in using the water from the analysed quarry lakes for the irrigation purposes (PN-84/C-04635, Ayers \& Westcott, 1985, Kaniszewski \& Treder, 2018).

The average lead content in the analysed quarry lakes fell into the range $2.52-3.62 \mu \mathrm{g} \cdot \mathrm{dm}^{-3}$, (Fig. 2, Table 1). The highest concentration (18.10 $\left.\mu \mathrm{g} \cdot \mathrm{dm}^{-3}\right)$ was noted in the Q1-G granite quarry (Table 1). No lead at all was detected in $80 \%$ of the samples of water from the Strzelin Quarry Lakes (Table 1), except for the autumn of 2017.
The lead concentrations found in the Strzelin Quarry Lakes were similar to the values (0.06$\left.15.0 \mu \mathrm{g} \cdot \mathrm{dm}^{-3}, 30.6-220.3 \mu \mathrm{g} \cdot \mathrm{dm}^{-3}\right)$ noted in lakes, especially uncontaminated ones (Piotrowski, 1997, Gwoździński et al., 2014, Zeng et al., 2012, Zeng et al., 2013, Wojtkowska, 2014) and similar to the lower lead concentration values (10.0-73.0 $\mu \mathrm{g} \cdot \mathrm{dm}^{-3}$ ) in water reservoirs (Avila-Pérez et al., 1999, Rosińska \& Dąbrowska, 2011). At the same time, they are decidedly lower than the lead content $\left(0.001-1.0 \mathrm{mg} \cdot \mathrm{dm}^{-3}\right)$ noted in the quarry lakes after the excavation of metal ores (Ramstedt et al., 2003, Kumar et al., 2009) as well as in the coal and lignite pit lakes $\left(0.011-6.3 \mathrm{mg} \cdot \mathrm{dm}^{-3}\right)$ (Stottmeister et al., 1999, Kumar et al., 2009, Hinwood et al, 2012). As the cadmium content in the analysed water was below $0.1 \mathrm{mg} \cdot \mathrm{dm}^{-3}\left(5 \mathrm{mg} \cdot \mathrm{dm}^{-3}\right.$ by FAO), it did not lead to any restrictions in using the water from the analysed quarry lakes for the irrigation purposes (PN-84/C-04635, Ayers \& Westcott, 1985, Kaniszewski \& Treder, 2018).

The average chromium content in the analysed quarry lakes fell into the range 2.06-6.24 $\mu \mathrm{g} \cdot \mathrm{dm}^{-3}$ (Fig. 2, Table 1). The highest concentration $\left(21.0 \mu \mathrm{g} \cdot \mathrm{dm}^{-3}\right)$ was noted in the Q3-G granite quarry (Table 1). In the autumn of 2016 and spring of 2017, chromium was detected in quarry lakes, whereas in the other cases ( $60 \%$ of samples) no chromium was found at all (Table 1). The chromium concentration in the water of the analysed Strzelin Quarry Lakes were similar to the lower values $0.95-2.27(22.17) \mu \mathrm{g} \cdot \mathrm{dm}^{-3}$ noted in lakes (Zeng et al., 2012, Zeng et al., 2013, Gwoździński et al., 2014), and the lower values $\sim 10-50$ (150) $\mu \mathrm{g} \cdot \mathrm{dm}^{-3}$ found in water reservoirs (Avila-Pérez et al., 1999, Rosińska and Dąbrowska, 2011). At the same time, they were lower than the chromium content $\left(0.001-0.47 \mathrm{mg} \cdot \mathrm{dm}^{-3}\right)$ noted in the coal and lignite pit lakes (Stottmeister et al., 1999, Kumar et al., 2009, Schultze et al., 2012). As the chromium content in the analysed water was below $0.1 \mathrm{mg} \cdot \mathrm{dm}^{-3}$ it did not lead to any restrictions in using the water from the analysed quarry lakes for the irrigation purposes (PN-84/C-04635, Ayers \& Westcott, 1985).

The average nickel content in the analysed quarry lakes fell into the range $0.46-7.98 \mu \mathrm{g} \cdot \mathrm{dm}^{-3}$, (Fig. 2, Table 1). The highest concentration $\left(39.80 \mu \mathrm{g} \cdot \mathrm{dm}^{-3}\right)$ was noted in the granite quarry Q1-G (Table 1). In $52 \%$ of the samples from the analysed quarry lakes (Table 1) no nickel was detected at all (2-4 samples per each specific quarry lake). The nickel content in the waters of the 
analysed Strzelin Quarry Lakes was similar to the concentrations $\left(0.8-5.2 \mu \mathrm{g} \cdot \mathrm{dm}^{-3}\right)$ noted in lakes (Zeng et al., 2012, Zeng et al., 2013, Gwoździński et al., 2014) and the content $\left(\sim 12.5-60.0 \mu \mathrm{g} \cdot \mathrm{dm}^{-3}\right)$ in water reservoirs (Avila-Pérez et al., 1999, Karadede \& Ünlü, 2000, Rosińska \& Dąbrowska, 2011). It is lower than the nickel content (0.09$\left.0.69 \mathrm{mg} \cdot \mathrm{dm}^{-3}\right)$ in the quarry lakes that emerged in metal ore mines (Kumar et al., 2009), and decidedly lower than the upper values of nickel concentration $\left(0.016-17.0 \mathrm{mg} \cdot \mathrm{dm}^{-3}\right)$ in the coal and lignite pit lakes (Stottmeister et al., 1999, Kumar et al., 2009, Schultze et al., 2010, Hinwood et al., 2012, Kumar et al., 2016). As the nickel content in the analysed water was below $1.0 \mathrm{mg} \cdot \mathrm{dm}^{-3}(0.2$ $\mathrm{mg} \cdot \mathrm{dm}^{-3}$ by FAO) its content did not lead to any restrictions in using the water for the irrigation purposes (PN-84/C-04635, Ayers \& Westcott, 1985, Kaniszewski \& Treder, 2018).

\section{SUMMARY AND CONCLUSIONS}

The Strzelin Quarry Lakes presented in the article emerged in the closed quarries of granitoides, quartzite shale, and marble result from the flooding by rainwater and ground water. They are characterised by relatively small surface areas ranging from 0.89 ha to 3.60 ha, but also relatively large depths of 10-25 m (max. $40 \mathrm{~m}$ ), so they may potentially store large amounts of water (Jawecki et. al., 2018, Jawecki et al., 2019b) and become a potential source of water to be used in agriculture (Jawecki 2019a), and for economic purposes.
The quarry lakes are supplied by rainwater, as well as the surface and sub-surface runoff from the direct catchment of the quarry lake. The concentration of heavy metals in the waters of the selected Strzelin Quarry Lakes is relatively low, similar to that in natural lakes. Simultaneously, the concentration of heavy metals in the water of the analysed Strzelin Quarry Lakes, is lower than in most pit lakes, for example in acidic AML and pit lakes that emerged after the excavation of metal ores.

According to the threshold values for the evaluation of the chemical condition of waters (Journal of Laws 2019.2149) the assessment of the content of zinc (average $14.40 \mu \mathrm{g} \cdot \mathrm{dm}^{-3}$ ), copper (average $21.13 \mu \mathrm{g} \cdot \mathrm{dm}^{-3}$ ), and chromium (average $4.26 \mu \mathrm{g} \cdot \mathrm{dm}^{-3}$ ) based on the threshold values of specific non-synthetic water quality indicators (Appendix No. 25, Journal of Laws 2019.2149) demonstrated that the water from the analysed quarry lakes should be classified as Class II. At the same time, the remaining analysed metals: cadmium (average $0.83 \mu \mathrm{g} \cdot \mathrm{dm}^{-3}$ ), lead (average $3.16 \mu \mathrm{g} \cdot \mathrm{dm}^{-3}$ ), and nickel (average $6.70 \mu \mathrm{g} \cdot \mathrm{dm}^{-3}$ ), assessed based on the values of environmental reference standards for priority substances in the water environment (Appendix No. 14, Journal of Laws 2019.2149), exceed the threshold values of annual average environmental quality standards (AA-EQS) and the maximum allowable concentration environmental quality standards (MACEQS) for natural water courses and lakes.

The content of heavy metals in the analysed Strzelin Quarry Lakes met the requirements on using water for irrigation provided in the international guidelines and Polish guidelines (Table 2).

Table 2. Evaluation of the usability of quarry lake water for irrigation purposes

\begin{tabular}{|c|c|c|c|c|c|c|c|c|c|c|}
\hline \multirow{2}{*}{ Parameter } & \multicolumn{2}{|c|}{ Q1-G } & \multicolumn{2}{|c|}{ Q2-TDG } & \multicolumn{2}{|c|}{ Q3-G } & \multicolumn{2}{|c|}{ Q4-QS } & \multicolumn{2}{|c|}{ Q5-M } \\
\hline & $\mathrm{PL}$ & FAO & $\mathrm{PL}$ & FAO & $\mathrm{PL}$ & FAO & $\mathrm{PL}$ & FAO & $\mathrm{PL}$ & FAO \\
\hline \multicolumn{11}{|l|}{$\mathrm{pH}^{2,3}(-)$} \\
\hline \multicolumn{11}{|l|}{ Zink ${ }^{1,2,3}\left(\mu \mathrm{g} \cdot \mathrm{dm}^{-3}\right)$} \\
\hline \multicolumn{11}{|l|}{ Copper ${ }^{2,3}\left(\mu \mathrm{g} \cdot \mathrm{dm}^{-3}\right)$} \\
\hline \multicolumn{11}{|l|}{ Cadmium ${ }^{1,2,3}\left(\mu \mathrm{g} \cdot \mathrm{dm}^{-3}\right)$} \\
\hline \multicolumn{11}{|l|}{ Lead $^{1,2,3}\left(\mu \mathrm{g} \cdot \mathrm{dm}^{-3}\right)$} \\
\hline \multicolumn{11}{|l|}{ Chromium ${ }^{2,3}\left(\mu \mathrm{g} \cdot \mathrm{dm}^{-3}\right)$} \\
\hline \multicolumn{11}{|l|}{ Nickel ${ }^{1,2,3}\left(\mu \mathrm{g} \cdot \mathrm{dm}^{-3}\right)$} \\
\hline \multicolumn{11}{|l|}{ Sum of heavy metals ${ }^{1,2}\left(\mathrm{mg} \cdot \mathrm{dm}^{-3}\right)$} \\
\hline \multicolumn{4}{|c|}{ Reference standard by PN-84/C- 04635 and FAO } & \multicolumn{3}{|c|}{ Met } & \multicolumn{4}{|c|}{ Not met } \\
\hline
\end{tabular}

PL $-{ }^{1}$ Kaniszewski \& Treder, 2018 or ${ }^{2}$ PN-84/C-04635. FAO; ${ }^{3}$ Ayers \& Westcott, 1985. 
Some restrictions on using the analysed water for irrigation were noted with respect to $\mathrm{pH}$ (in quarry Q1-G), but this issue has been discussed more widely in the referenced study by Jawecki and coworkers, (2019a).

The conducted research allowed the authors to formulate the following conclusions:

1. The content of heavy metals $\mathrm{Zn}, \mathrm{Cu}, \mathrm{Cr}, \mathrm{Cd}$, $\mathrm{Pb}$, and $\mathrm{Ni}$ ) in the waters of the analysed Strzelin Quarry Lakes met the requirements on using water for irrigation provided in the international and Polish guidelines.

2. The concentrations of heavy metals found in the waters of the analysed Strzelin Quarry Lakes were similar to those in natural lakes, decidedly lower than in most pit lakes, especially AML, and the pit lakes emerging after the excavation of metal ores.

3. As far as the concentration of zinc, copper, and chromium are concerned, the water in the analysed Strzelin Quarry Lakes met the requirements of surface water quality indicators for Class II of the chemical state of the waters, whereas the content of cadmium, lead, and nickel exceeded the threshold values of AAEQS and MAC-EQS concentrations for natural water courses and lakes.

\section{REFERENCES}

1. Avila-Pérez P., Balcázar M., Zarazúa-Ortega G., Barceló-Quintal I., Díaz-Delgado C. 1999. Heavy metal concentrations in water and bottom sediments of a Mexican reservoir. Science of The Total Environment, 234(1-3), 185-196.

2. Axler R., Yokom S., Tikkanen C., McDonald M., Runke H., Wilcox D., Cady B. 1998. Restoration of a Mine Pit Lake from Aquacultural Nutrient Enrichment. Restoration Ecology, 6(1), 1-19. DOI: 10.1046/j.1526-100x.1998.00612.x.

3. Ayers R.S. and Westcott D.W. 1985. Water quality for agriculture, FAO irrigation and drainage paper 29. Rev. 1. Food and Agriculture Organization of the United Nations, Rome.

4. Castendyk D.N., Mauk J.L., Webster J.G. 2005. A mineral quantification method for wall rocks at open pit mines, and application to the Martha $\mathrm{Au}-\mathrm{Ag}$ mine, Waihi, New Zealand. Applied Geochemistry, 20, 135-156.

5. Chudzik W. 2012. The process of mined land reclamation in natural aggregate quarries exemplified by the sand and gravel quarry Dębina Łętowska. AGH Journal of Mining and Geoengineering, 36(1), 89-96.
6. Czerniawska-Kusza I., Brożonowicz A. 2014. Zoobenthos in post-exploitation reservoirs of marls and limestone in Opole Silesia. Polish Journal of Natural Sciences, 29(4), 307-318.

7. Denimal S., Bertrand C., Mudry J., Paquette Y., Hochart M., Steinmann M. 2005. Evolution of the aqueous geochemistry of mine pit lakes -Blanzy-Montceau-les-Mines coal basin (Massif Central, France): origin of sulfate contents, effects of stratification on water quality. Applied Geochemistry, 20, 825-839.

8. Domashenko, Y., and Vasilyev, S. 2018. Agroecological Substantiation for the Use of Treated Wastewater for Irrigation of Agricultural Land. Journal of Ecological Engineering, 19(1), 48-54. https://doi. org/10.12911/22998993/79567.

9. Doupé R.G., Lymbery A.J. 2005. Environmental risks associated with beneficial end uses of mine lakes in Southwestern Australia. Mine Water and the Environment, 24(3), 134-138.

10. Doyle, G.A., Runnells D.D. 1997. Physical limnology of existing mine pit lakes. Mining Engineering, 49, 76-80.

11. EEA Report No 2/2009. Water resources across Europe - confronting water scarcity and drought. Luxembourg: Office for Official Publications of the European Communities, 2009. DOI 10.2800/16803.

12. Ejsmont-Karabin J. 1995. Rotifer occurrence in relation to age, depth and trophic state of quarry lakes. Hydrobiologia, 313/314, 21-28.

13. Elzwayie, A., Afan, H.A., Allawi, M.F., El-Shafie A. 2017. Heavy metal monitoring, analysis and prediction in lakes and rivers: state of the art. Environ Sci Pollut Res, 24,12104-12117. DOI 10.1007/ s11356-017-8715-0.

14. Frankowski, P., Zbierska, J. 2015. Ocena jakości wody, potencjału ekologicznego małych zbiorników wodnych odbudowanych $\mathrm{w}$ krajobrazie rolniczym Wielkopolski. Nauka Przyr. Technol., 9, 1, \#7. DOI: 10.17306/J.NPT.2015.1.7.

15. Galas J. 2003. Limnological Study on a Lake Formed in a Limestone Quarry (Kraków, Poland). I. Water Chemistry. Polish Journal of Environmental Studies, 12(3), 297-300.

16. Grünewald U. 2001. Water resources management in river catchments influenced by lignite mining. Ecological Engineering, 17,143-152.

17. GUS 2019: Ochrona Środowiska 2019, Warszawa 2019.

18. Gwoździński K., Mazur J., Pieniążek A. 2014. Concentrations of metals in water of unmonitored lakes near a landscape park. Pol. J. Environ. Stud. 23(4), 1317-1321.

19. Hinwood A. L., Heyworth J., Tanner H., McCullough C. 2012. Recreational use of acidic pit lakes-human health considerations for post closure 
planning. Journal of Water Resource and Protection, 4, 1061-1070.

20. Jawecki B. 2017. Rola kamieniołomów w kształtowaniu krajobrazu na przykładzie ziemi strzelińskiej, Monografie Uniwersytet Przyrodniczy we Wrocławiu vol. 205. Wydawnictwo Uniwersytetu Przyrodniczego we Wrocławiu, p. 268.

21. Jawecki B. 2019. Kamień w architekturze i budownictwie ziemi strzelińskiej, Monografie - Uniwersytet Przyrodniczy we Wrocławiu, vol. 222. Wydawnictwo Uniwersytetu Przyrodniczego we Wrocławiu, p. 170.

22. Jawecki B., Dąbek P.B., Pawęska K., Wei X. 2018. Estimating Water Retention in Post-mining Excavations Using LiDAR ALS Data for the Strzelin Quarry, in Lower Silesia. Mine Water and the Environment, 37(4), 744-753. https://doi.org/10.1007/ s10230-018-0526-0.

23. Jawecki B., Kowalczyk T, Feng Y. 2019a. The evaluation of the possibility to use the water from quarry lakes for irrigation. J. Ecol. Eng. 20(9), 188-201, https://doi.org/10.12911/22998993/112490.

24. JaweckiB., Mirski J.2018. Wstępna ocena zawartości biogenów w wodach zalanych nieczynnych kamieniołomów położonych na terenach wiejskich (Preliminary evaluation of nutrients concentration in quarry lakes located on the rural areas). Inżynieria Ekologiczna, (Ecological Engineering) 19(6), 1-13, https://doi.org/10.12912/23920629/94957.

25. Jawecki B., Szewrański S., Stodolak R., Wang Z. 2019b. The use of digital terrain models to estimate the pace of filling the pit of a Central European Granite Quarry with water Water, 11(11), 2298, DOI:10.3390/w11112298.

26. Journal of Laws 2019.2149. Rozporządzenie Ministra Gospodarki Morskiej, Żeglugi Śródlądowej z dnia 11 października 2019 r. w sprawie klasyfikacji stanu ekologicznego, potencjału ekologicznego, stanu chemicznego oraz sposobu klasyfikacji stanu jednolitych części wód powierzchniowych, a także środowiskowych norm jakości dla substancji priorytetowych, Dz.U. 2019 poz. 2149.

27. Kaniszewski S., Treder W. 2018. Jakość wody do nawadniania, fertygacji, metody uzdatniania. [In] Walczak, J. (ed.) Ograniczenie zanieczyszczenia azotem pochodzenia rolniczego metodą poprawy jakości wód. Fundacja na rzecz Rozwoju Polskiego Rolnictwa, Warszawa 2018.

28. Karadede H., Ünlü E. 2000. Concentrations of some heavy metals in water, sediment and species from the Atatürk Dam Lake (Euphrates), Turkey. Chemosphere, 41, 1371-1376.

29. Klapper H., Geller W. 2001. Water quality management of mining lakes - a new field of applied hydrobiology. Acta hydrochim. hydrobiol. 29(6-7), 363-374.
30. Kleeberg A., Grüneberg B. 2005. Phosphorus mobility in sediments of acid mining lakes, Lusatia, Germany. Ecological Engineering, 24, 89-100.

31. Kołodziejczyk U. 2009. Hydrological, geological and geochemical conditions determining reclamation of post - mine land in the region of Łęknica. Gospodarka Surowcami Mineralnymi, 25(3), 190-201.

32. Kumar N.R., McCullough C.D. Lund M.A., Larranaga S.A. 2016. Assessment of factors limiting algal growth in acidic pit lakes - a case study from Western Australia, Australia. Environmental Science and Pollution Research, 23, 5915-5924. DOI 10.1007/s11356-015-5829-0

33. Kumar R. N., McCullough C. D., Lund M. A. 2009. Water Resources in Australian Mine Pit Lakes. Mining Technology, 118(3-4), 204-211. DOI:10.1179/1 $74328610 X 12682159815028$.

34. Łabędzki L. 2016. Actions and measures for mitigation drought and water scarcity in agriculture. Journal of Water and Land Development, 29(IVVI), 3-10. DOI: 10.1515/jwld-2016-0007.

35. Lykhovyd, P. V., Lavrenko, S., Lavrenko, N., Dementiieva, O. 2019. Agro-Environmental Evaluation of Irrigation Water from Different Sources, Together with Drainage and Escape Water of Rice Irrigation Systems, According to its Impact on Maize. Journal of Ecological Engineering, 20(2), 1-7. https://doi.org/10.12911/22998993/94916.

36. Mayne C.D. 1994. The Limnology of Three Limestone Rock Quarries in East-Central Nebraska and Western Iowa. Transactions of the Nebraska Academy of Sciences, 21, 1-7.

37. Malczewska B., Czaban S., Jawecki B. 2018. Occurrence of iron, manganese, and selected trace elements in water from household wells exposed to the impact of a mining area. J. Elem., 23(4), 1319-1329. DOI: $10.5601 /$ jelem.2017.22.4.1547.

38. McCullough C. D. 2008. Approaches to remediation of acid mine drainage water in pit lakes. International Journal of Mining, Reclamation and Environment, 22(2), 105-119.

39. McCullough C.D., Lund M.A. 2006. Opportunities for sustainable mining pit lakes in Australia. Mine Water and the Environment, 25, 220-226.

40. Molenda T. 2006. Górnicze środowiska akwatyczne - obiekty obserwacji procesów hydrologicznobiologicznych. Prace Naukowe Instytutu Górnictwa Politechniki Wrocławskiej, 117(32), 239-250.

41. Nixdorf B., Lessmann D., Deneke R. 2005. Mining lakes in a disturbed landscape: Application of the EC Water Framework Directive and future management strategies. Ecological Engineering, 24, 67-73.

42. Park, D.M., S.A. White, L.B. McCarty and N.A. Menchyk. 2014. Interpreting irrigation water quality reports. Clemson University Cooperative Extension. CU-14-700. 
43. Patro M., Zubala T. 2012. Possibilities of shaping the water retention in agricultural landscape. Teka Kom. Ochr. Kszt. Środ. Przyr. - OL PAN, 9, 143-152.

44. Pertsemli E, Voutsa D 2007. Distribution of heavy metals in lakes doirani and kerkini, northern Greece. J Hazard Mater, 148, 529-537.

45. Piotrowski S. 1997. Zawartość metali ciężkich w wybranych elementach ekosystemu jeziora Dąbie (NW Polska). Przegląd Geologiczny, 45(6), 619-621.

46. PN-84/C-04635. Woda do nawadniania roślin na użytkach rolnych oraz do ich opryskiwania chemicznymi środkami ochrony roślin.

47. Puczyńska I., Skrzypski J. 2009. Integracja działań biologicznych, technicznych jako podstawa intensyfikacji procesów samooczyszczania się zbiorników zaporowych (na przykładzie Zbiornika Sulejowskiego). Ecological Chemistry and Engineering S, 16(S2), 221-235.

48. Ramstedt M., Carlsson E., Lövgren L. 2003. Aqueous geochemistry in the Udden pit lake, northern Sweden. Applied Geochemistry, 18, 97-108.

49. Ravazzani G., Giudici, I., Schmidt, C., and Mancini, M. 2011. Evaluating the Potential of Quarry Lakes for Supplemental Irrigation. Journal of Irrigation and Drainage Engineering 137(80), 564-571. DOI. 10.1061/(ASCE)IR.1943-4774.0000321.

50. Rosińska A., Dąbrowska L., 2011. PCB, metale ciężkie w wodzie, osadach dennych zbiornika Kozłowa Góra. Archives of Environmental Protection, 37(4), 61-72.

51. Schultze M., Pokrandt K-H., Hille W. 2010. Pit lakes of the Central German lignite mining district: Creation, morphometry and water quality aspects. Limnologica, 40(2), 148-155. http://dx.doi. org/10.1016/j.limno.2009.11.006.

52. Singleton V.L., Jacob B., Feeney M.T. Little J.C. 2013. Modeling a proposed quarry reservoir for raw water storage in Atlanta, Georgia. Journal of Environmental Engineering, 139(1), 70-78. DOI: 10.1061/(ASCE)EE.1943-7870.0000582.

53. Stottmeister U., Glässer W., Klapper H., Weißbrodt E., Eccarius B., Kennedy C., Schultze M., Wendt-Potthoff K., Frömmichen R., Schreck P., Strauch G. 1999. Strategies for Remediation of
Former Opencast Mining Areas in Eastern Germany. In: Azcue J.M. (Ed.) Environmental Impacts of Mining Activities. Environmental Science. Springer, Berlin, Heidelberg, https://doi. org/10.1007/978-3-642-59891-3_16.

54. Tarjuelo J.M., De-Juan J.A., Moreno M.A., Ortega J.F. 2010. Review. Water resources deficit andwater engineering. Span J Agric Res, 8, 102-121.

55. Treder W. 2016. Systemy nawadniana upraw warzywnych. Tradycyjna, integrowana produkcja warzyw, innowacyjne metody ich przechowywania. TRAFOON project is funded by the European Community's Seventh Framework Programme (FP7/20072013) under grant agreement no. 613912. https:// www.trafoon.org/sites/trafoon.org/files/download/890/boguchwala_waldemar_treder_201604. pdf (dostęp 2019-07-20).

56. Vukosav P., Mlakar M., Cukrov N., KwokalŽ., Pižeta I., Pavlus N., Špoljarić I., Vurnek M., Brozinčević A., Omanović D. 2014. Heavy metal contents in water, sediment and fish in a karst aquatic ecosystem of the Plitvice Lakes National Park (Croatia). Environ Sci Pollut Res, 21(5), 3826-3839. https:// doi.org/10.1007/s11356-013-2377-3.

57. Walczykiewicz T. 2014. Scenarios of Water Resources Development in Poland up to 2030. Water Resources, 41(6), 763-773. DOI: 10.1134/ S0097807814060219.

58. Wiejaczka Ł. 2011. Wpływ zbiornika Klimkówka na abiotyczne elementy środowiska przyrodniczego w wolnie Ropy. Prace geograficzne 229, IGiPZ PAN, Warszawa.

59. Wojtkowska M. 2014. Metale ciężkie w wodzie, osadach, roślinach Jeziora Zegrzyńskiego (Heavy metals in water, sediments and plants of the Zegrzyński Lake). Progress in Plant Protection, 54 (1), 5-101. DOI: http://dx.doi.org/10.14199/ppp-2014-017.

60. Zeng J., Yang L. Y., Chen X., Chuai X., Wu Q. L. 2012. Spatial distribution and seasonal variation of heavy metals in water and sediments of Taihu Lake. Pol. J. Environ. Stud. 21(5), 1489-1496.

61. Zeng J., Yang L. Y., Chuai X. M., Chen X. F., Zhao H. Y., Wu Q. L. 2013. Comparison of metal(loid) concentrations in water, sediments and fish from two large shallow lakes. Int. J. Environ. Sci. Technol. 10, 1209-1218. DOI 10.1007/s13762-013-0246-8. 